\title{
Modifikasi Suhu Uji Pemunculan Radikula untuk Mempersingkat Pengujian Vigor Benih Jagung
}

\section{Temperature Modification of Radicle Emergence Test to Shorten the Corn Seed Vigor Test}

\author{
Aghniya Ul Khusna ${ }^{1}$, Ahmad Zamzami², dan Satriyas Ilyas ${ }^{2 *}$ \\ ${ }^{1}$ Program Studi Agronomi dan Hortikultura, Departemen Agronomi dan Hortikultura, Institut Pertanian Bogor \\ ${ }^{2}$ Departemen Agronomi dan Hortikultura, Fakultas Pertanian, Institut Pertanian Bogor \\ (IPB University), Jl. Meranti, Kampus IPB Darmaga, Bogor 16680, Indonesia
}

Diterima 20 Desember 2021/Disetujui 30 Desember 2021

\begin{abstract}
Radicle emergence (RE) is a rapid vigor test recommended by ISTA in 2014 for corn seeds at $20^{\circ} \mathrm{C}$ for 66 hours. The purpose of this study was to develop an RE test of corn seeds at $25^{\circ} \mathrm{C}$ and determine a single observation time to shorten the period of the vigor test. The experiments were conducted at IPB from December 2019 to March 2020. The experimental design used in the RE test was split-plot, with nine seed lots (cultivars) as main plots and 14 observation times (27, 30, 33, $36,39,42,45,48,51,54,57,60,63$, and 66 hours after sowing) as subplots. The completely randomized block design with one factor (seed lots) was used in the laboratory and field experiments. The result of the RE test was then correlated with seed and seedling quality parameters. The experimental results revealed that the RE test on corn seeds using between paper germinating method at $25{ }^{\circ} \mathrm{C}$ and observed at 51 hours \pm 15 minutes after sowing, was closely correlated and could predict the normal germination percentage, mean germination time, vigor index, speed of germination, and mean emergence time.
\end{abstract}

Keywords: correlation, cultivar, normal germination percentage, seed lot, seed vigor, seedling vigor

\section{ABSTRAK}

Radicle emergence (RE) atau pemunculan radikula adalah uji vigor cepat yang direkomendasikan ISTA tahun 2014 untuk benih jagung pada suhu $20^{\circ} \mathrm{C}$ selama 66 jam. Tujuan penelitian ini adalah mengembangkan uji RE benih jagung pada suhu $25^{\circ} \mathrm{C}$ dan menentukan satu waktu pengamatan yang tepat untuk mempersingkat periode pengujian vigor benih jagung. Penelitian dilakukan di Laboratorium Penyimpanan dan Pengujian Mutu Benih, dan Kebun Percobaan Cikabayan IPB mulai Desember 2019 sampai dengan Maret 2020. Rancangan percobaan yang digunakan dalam pengujian RE yaitu splitplot, dengan sembilan lot benih (varietas) sebagai petak utama dan 14 waktu pengamatan (jam ke- 27, 30, 33, 36, 39, 42, $45,48,51,54,57,60,63$, dan 66 setelah pengecambahan) sebagai anak petak. Rancangan kelompok lengkap teracak satu faktor (lot benih) digunakan untuk pengujian mutu benih di laboratorium dan vigor bibit di lapangan. Hasil uji RE kemudian dikorelasikan dengan daya berkecambah, vigor benih, dan vigor bibit. Hasil penelitian menunjukkan bahwa uji RE pada benih jagung dengan metode uji antar kertas pada suhu $25^{\circ} \mathrm{C}$ dan diamati saat 51 jam \pm 15 menit setelah pengecambahan terbukti berkorelasi erat dan dapat memprediksi daya berkecambah, rataan waktu perkecambahan, indeks vigor, kecepatan tumbuh, dan rataan waktu pemunculan bibit.

Kata kunci: daya berkecambah, korelasi, lot benih, varietas, vigor benih, vigor bibit

\section{PENDAHULUAN}

Benih bermutu tinggi dicirikan oleh tingkat kemurnian, viabilitas dan vigor benih yang tinggi dan bebas dari patogen terbawa benih. Vigor benih mencakup kecepatan dan keserempakan perkecambahan, daya simpan, dan kemampuan tumbuh di lapangan. Uji vigor merupakan indeks mutu benih yang lebih sensitif dalam mendeteksi

\footnotetext{
* Penulis untuk korespondensi. e-mail: satriyas_ilyas@apps.ipb. ac.id
}

deteriorasi benih daripada uji daya berkecambah (Ilyas, 2012). Oleh karena itu, untuk mendeteksi mutu fisiologis benih telah dikembangkan berbagai uji vigor.

Uji radicle emergence (RE) atau pemunculan radikula merupakan salah satu uji vigor benih. Uji RE dilakukan dengan menghitung persentase benih yang radikulanya telah muncul minimal sepanjang $2 \mathrm{~mm}$ pada sekali pengamatan di awal perkecambahan. Tinggi atau rendahnya nilai RE menjadi penanda vigor benih. Lot benih dengan nilai RE yang rendah menggambarkan lambatnya perkecambahan yang merupakan ekspresi fisiologis awal dari penuaan benih, 
penyebab utama penurunan vigor. Lamanya pemunculan radikula disebabkan oleh penuaan benih (Onwimol et al., 2012). Menurut Matthews dan Powell (2011), uji RE berkorelasi erat dengan rataan waktu perkecambahan (mean germination time / MGT), semakin rendah nilai MGT maka waktu yang dibutuhkan benih untuk berkecambah semakin cepat. Yin et al. (2018) menyatakan bahwa kecepatan pemunculan radikula erat kaitannya dengan tingkat mobilisasi pati pada benih.

Uji RE awalnya dikembangkan pada benih jagung oleh Matthews dan Hosseini (2006) dengan menghasilkan waktu pengamatan uji RE benih jagung yaitu 66 jam setelah dikecambahkan pada suhu $20{ }^{\circ} \mathrm{C}$ atau 6 hari jika pada suhu $13{ }^{\circ} \mathrm{C}$. Hasil penelitian tersebut diakui sebagai salah satu uji vigor dalam International Rules for Seed Testing (ISTA 2014). Penelitian ini merupakan pengembangan uji RE yang telah divalidasi oleh ISTA tersebut, namun dengan menggunakan suhu pengecambahan yang lebih tinggi yaitu sekitar $25^{\circ} \mathrm{C}$ pada berbagai varietas jagung komersil di Indonesia. Penggunaan suhu $25^{\circ} \mathrm{C}$ diharapkan lebih mudah diaplikasikan di Indonesia, sekaligus dapat mempercepat waktu pengujian RE benih jagung dibandingkan suhu $20^{\circ} \mathrm{C}$. Oleh karena itu, tujuan penelitian ini adalah mengembangkan uji RE benih jagung pada suhu $25^{\circ} \mathrm{C}$ dan menentukan satu waktu pengamatan yang tepat untuk mempersingkat periode pengujian vigor benih jagung.

\section{BAHAN DAN METODE}

Penelitian dilakukan di Laboratorium Ilmu dan Teknologi Benih dan Kebun Percobaan Cikabayan, Departemen Agronomi dan Hortikultura, IPB, Dramaga, Bogor. Penelitian dilakukan pada bulan Desember 2019 sampai dengan Maret 2020. Benih jagung komposit yang digunakan berasal dari Balai Penelitian Tanaman Serealia yaitu varietas Bisma, Lamuru, Sukmaraga, Srikandi Kuning, Gumarang, Anoman, dan Provit A1. Benih jagung hibrida yang diperoleh dari PT BISI International Tbk yaitu varietas BISI 2 dan BISI 18. Sampel benih diukur kadar airnya menggunakan metode oven suhu tinggi $130-133{ }^{\circ} \mathrm{C}$ selama 4 jam (ISTA 2014). Setiap sampel diulang sebanyak empat kali masing-masing $4.5 \pm 0.5$ g. Nilai KA benih tertinggi pada varietas Lamuru (9.8\%) tetapi tidak berbeda nyata dengan varietas Anoman (9.4\%), BISI 18 (9.4\%), Bisma (9.3\%), dan Gumarang (9\%). Nilai KA terendah pada varietas Provit A1 (8.2\%) tetapi tidak berbeda nyata dengan varietas Sukamaraga (8.7\%), Srikandi Kuning (8.5\%), dan BISI 2 (8.5\%).

Rancangan percobaan yang digunakan dalam pengujian RE yaitu split-plot, dengan sembilan lot benih (varietas) sebagai petak utama dan 14 waktu pengamatan (jam ke- 27, 30, 33, 36, 39, 42, 45, 48, 51, 54, 57, 60, 63, dan 66 setelah pengecambahan) sebagai anak petak. Pengujian RE menggunakan metode uji antar kertas dengan tisu towel di dalam boks plastik. Setiap lot benih diulang empat kali masing-masing ulangan 50 butir benih. Pengamatan dilakukan terhadap persentase jumlah benih yang telah muncul radikulanya minimum 2 mm (ISTA 2014).
Pengujian mutu benih di laboratorium yaitu uji daya berkecambah (DB), bobot kering kecambah normal (BKKN), indeks vigor (IV), mean germination time (MGT), kecepatan tumbuh $\left(\mathrm{K}_{\mathrm{CT}}\right)$, dan laju pemunculan kecambah (LPK). Pengujian mutu bibit di lapangan untuk menguji daya tumbuh (DT) dan rataan waktu pemunculan bibit atau mean emergence time (MET). Percobaan menggunakan rancangan kelompok lengkap teracak faktor tunggal yaitu lot benih. Pengujian DB, IV, $\mathrm{K}_{\mathrm{CT}}$, BKKN, dan LPK dilakukan dengan metode uji kertas digulung dalam plastik. Setiap varietas diulang sebanyak empat kali masing-masing ulangan 50 butir benih. Benih dikecambahkan dalam germinator standar suhu $\pm 25^{\circ} \mathrm{C}$. Pengujian mutu benih di lapangan dengan menanam sembilan varietas jagung dalam petakan berukuran $1.5 \mathrm{~m}$ x $7.5 \mathrm{~m}$ dengan jarak tanam $15 \mathrm{~cm} \times 15 \mathrm{~cm}$, dan jarak antar petakan $50 \mathrm{~cm}$. Suhu rata-rata harian selama penelitian di Dramaga, Bogor berkisar 25.7-27.9 ${ }^{\circ} \mathrm{C}$.

Daya berkecambah dihitung berdasarkan persentase jumlah kecambah normal pada hitungan pertama (hari ke-4) dan hitungan kedua (hari ke-7). Indeks vigor adalah persentase jumlah kecambah normal pada hitungan pertama. Pengukuran $\mathrm{K}_{\mathrm{CT}}$ melalui penjumlahan dari persentase pertambahan kecambah normal per etmal (24 jam) mulai hari pertama sampai 7 hari setelah tanam (HST). BKKN dihitung berdasarkan bobot kering kecambah normal pada hari hitungan kedua dari uji DB yang dikeringkan pada suhu $80^{\circ} \mathrm{C}$ selama 24 jam. Laju pertumbuhan kecambah dihitung dari rasio antara total BKKN dan jumlah kecambah normal (KN). Daya tumbuh dihitung berdasarkan persentase bibit jagung yang tumbuh normal di lapangan 14 HST. Mean emergence time dihitung berdasarkan rataan waktu pemunculan bibit (poros kecambah) ke permukaan tanah setiap hari hingga 14 HST.

\section{HASIL DAN PEMBAHASAN}

\section{Pengujian Mutu Benih di Laboratorium dan Mutu Bibit di Lapangan}

Sembilan lot benih jagung yang berbeda varietas menunjukkan perbedaan nyata pada tolok ukur DB, IV, $\mathrm{K}_{\mathrm{CT}}$, BKKN, LPK, MGT, dan KA (Tabel 1). Berdasarkan beberapa tolok ukur vigor dan viabilitas tersebut, lot benih varietas BISI 18 merupakan lot dengan mutu benih tertinggi. Lot benih Lamuru dan Anoman konsisten menunjukkan mutu benih terendah. Sementara itu lot benih lainnya tergolong bermutu tinggi namun masih dibawah BISI 18 dan dengan urutan mutu yang fluktuatif. Hal ini menunjukkan bahwa lot benih yang digunakan memiliki tingkat viabilitas dan vigor yang beragam. Hal ini akan sangat baik untuk menunjukkan apakah nilai RE juga nantinya akan beragam dan berkorelasi.

Hasil pengamatan di lapangan (Tabel 2) menunjukkan bahwa daya tumbuh (DT) dari sembilan lot benih yang diuji terkelompok menjadi dua. Lot dengan daya tumbuh tinggi adalah lot benih varietas BISI 2, Gumarang, BISI 18, Provit A1, Sukmaraga, Srikandi kuning, dan Bisma. Sementara kelompok lot benih yang menunjukkan DT yang sedang 
Tabel 1. Hasil pengujian mutu benih jagung di laboratorium

\begin{tabular}{|c|c|c|c|c|c|c|}
\hline $\begin{array}{l}\text { Kode } \\
\text { varietas }\end{array}$ & DB (\%) & IV (\%) & $\begin{array}{c}\mathrm{K}_{\mathrm{CT}} \\
\left(\% . \text { etmal }^{-1}\right)\end{array}$ & $\begin{array}{c}\text { BKKN } \\
(\mathrm{g})\end{array}$ & $\begin{array}{c}\text { LPK } \\
\text { (mg per KN) }\end{array}$ & $\begin{array}{l}\text { MGT } \\
\text { (jam) }\end{array}$ \\
\hline $\mathrm{V} 1$ & $90.5 b$ & $42.5 b$ & $32.9 \mathrm{bc}$ & $2.25 \mathrm{~d}$ & $51.78 \mathrm{bc}$ & $44.35 \mathrm{~d}$ \\
\hline V2 & $97.0 \mathrm{a}$ & $56.0 \mathrm{a}$ & $32.9 \mathrm{bc}$ & $2.87 \mathrm{a}$ & $60.03 a$ & $40.38 \mathrm{e}$ \\
\hline V3 & $90.5 b$ & $26.5 d$ & $30.7 \mathrm{c}$ & $2.17 d$ & $48.82 \mathrm{c}$ & $48.88 \mathrm{c}$ \\
\hline V4 & $78.0 \mathrm{c}$ & $9.5 \mathrm{e}$ & $21.4 \mathrm{~d}$ & $1.77 \mathrm{e}$ & $44.55 \mathrm{~d}$ & $56.56 \mathrm{a}$ \\
\hline V5 & $72.5 \mathrm{~d}$ & $14.0 \mathrm{e}$ & $19.5 \mathrm{~d}$ & $1.29 \mathrm{f}$ & $36.43 \mathrm{e}$ & $54.13 b$ \\
\hline V6 & $94.5 \mathrm{ab}$ & $34.0 \mathrm{c}$ & $39.6 \mathrm{a}$ & $2.68 \mathrm{ab}$ & $55.28 \mathrm{~b}$ & $48.75 c$ \\
\hline V7 & $91.5 b$ & $28.5 \mathrm{dc}$ & $32.2 \mathrm{c}$ & $2.35 \mathrm{~cd}$ & $50.62 \mathrm{c}$ & $50.54 c$ \\
\hline V8 & $94.5 \mathrm{ab}$ & $41.5 b$ & $37.6 a b$ & $2.57 b c$ & $55.78 \mathrm{~b}$ & $45.75 \mathrm{~d}$ \\
\hline V9 & $97.0 \mathrm{a}$ & $34.0 \mathrm{c}$ & $37.2 \mathrm{ab}$ & $2.47 \mathrm{bcd}$ & $49.99 \mathrm{c}$ & $44.35 \mathrm{~d}$ \\
\hline $\operatorname{Pr}(>F)$ & $* *$ & $* *$ & $* *$ & $* *$ & $* *$ & $* *$ \\
\hline KK (\%) & 3.37 & 11.9 & 10.09 & 7.96 & 5.22 & 2.73 \\
\hline
\end{tabular}

Keterangan: Angka-angka yang diikuti huruf yang sama pada kolom yang sama menunjukkan nilai tidak berbeda nyata dengan uji DMRT pada $\alpha=5 \%$, **berpengaruh sangat nyata pada $\alpha=1 \%$. KA = kadar air; $\mathrm{DB}=$ daya berkecambah; $\mathrm{IV}=$ indeks vigor; $\mathrm{K}_{\mathrm{CT}}=$ kecepatan tumbuh; BKKN = bobot kering kecambah normal; LPK = laju pertumbuhan kecambah; MGT = mean germination time; $\mathrm{KN}$ = kecambah normal; KK = koefisien keragaman; V1 = BISI 2; V2 = BISI 18; V3 = Bisma; V4 = Lamuru; V5 = Anoman; V6 = Provit A1; V7 = Sukmaraga; V8 = Srikandi Kuning; V9 = Gumarang

adalah lot benih varietas Lamuru dan Anoman. Hal ini secara umum menunjukkan pola yang mirip dengan mutu benih yang diuji di laboratorium dimana lot benih varietas Lamuru dan Anoman konsisten menunjukkan mutu terendah dibanding lot benih lainnya.

Tabel 2. Hasil pengujian mutu bibit jagung di lapangan

\begin{tabular}{lcc}
\hline $\begin{array}{l}\text { Kode } \\
\text { varietas }\end{array}$ & Daya tumbuh (\%) & MET (hari) \\
\hline V1 & $95.5 \mathrm{a}$ & $4.880 \mathrm{~b}$ \\
V2 & $94.0 \mathrm{a}$ & $4.46 \mathrm{c}$ \\
V3 & $89.5 \mathrm{a}$ & $5.25 \mathrm{~b}$ \\
V4 & $82.5 \mathrm{~b}$ & $5.98 \mathrm{a}$ \\
V5 & $80.5 \mathrm{~b}$ & $6.12 \mathrm{a}$ \\
V6 & $94.0 \mathrm{a}$ & $4.91 \mathrm{~b}$ \\
V7 & $93.5 \mathrm{a}$ & $5.22 \mathrm{~b}$ \\
V8 & $92.5 \mathrm{a}$ & $4.99 \mathrm{~b}$ \\
V9 & $95.0 \mathrm{a}$ & $5.16 \mathrm{~b}$ \\
Pr $(>$ F $)$ & $* *$ & $* *$ \\
KK $(\%)$ & 4.56 & 5.01 \\
\hline
\end{tabular}

Keterangan: Angka-angka yang diikuti huruf yang sama pada kolom yang sama menunjukkan nilai tidak berbeda nyata dengan uji DMRT pada $\alpha=5 \%$,**berpengaruh sangat nyata pada $\alpha=1 \%$. DT = daya tumbuh 14 hari setelah tanam; MET = mean emergence time; $\mathrm{V} 1=$ BISI 2; V2 = BISI 18; V3 = Bisma; V4 = Lamuru; $\mathrm{V} 5=$ Anoman; V6 = Provit A1; V7 = Sukmaraga; V8 $=$ Srikandi Kuning; V9 = Gumarang
Pola urutan nilai MET dari sembilan lot benih varietas jagung yang diuji tetap menunjukkan bahwa lot benih varietas Lamuru dan Anoman merupakan yang terendah dibanding lot benih yang lain. Nilai MET yang tinggi menunjukkan pertumbuhan kecambah yang lambat di lapangan. Sementara itu lot benih varietas BISI 18 kembali menunjukkan indikasi mutu tertinggi dengan nilai MET yang terendah dibandingkan lot benih lainnya. Nilai MET yang rendah menunjukkan pertumbuhan kecambah lebih cepat di lapangan. Hasil penelitian Demir et al. (2011) pada benih viola (Viola tricolor L.) menunjukkan, semua uji vigor (accelerated aging, saturated salt accelerated aging, dan MGT) berkorelasi erat dengan daya tumbuh (seedling emergence) dan MET.

\section{Penentuan Waktu Pengamatan Uji RE}

Pengamatan pemunculan radikula (RE) pada sembilan lot benih berbagai varietas jagung dilakukan antara jam ke-27 sampai ke-66 setelah dikecambahkan di germinator standar pada suhu $25^{\circ} \mathrm{C}$. Nilai RE menunjukkan perbedaan nyata antar lot benih varietas jagung pada setiap waktu pengamatan setelah dikecambahkan. Persentase RE setiap waktu pengamatan menunjukkan hasil yang terus meningkat seiring bertambah lamanya waktu pengamatan. Nilai RE antar lot benih selama jam ke-27 sampai ke-66 setelah dikecambahkan (yang membentuk kurva) secara nyata menunjukkan perbedaan kecepatan pemunculan radikula. Lot benih varietas BISI 18 menunjukkan kecepatan pemunculan radikula tercepat yang diikuti dengan lot benih varietas Gumarang, BISI 2, Srikandi Kuning, Provit A1, Bisma, Sukmaraga, Anoman dan Lamuru (Gambar 1). 


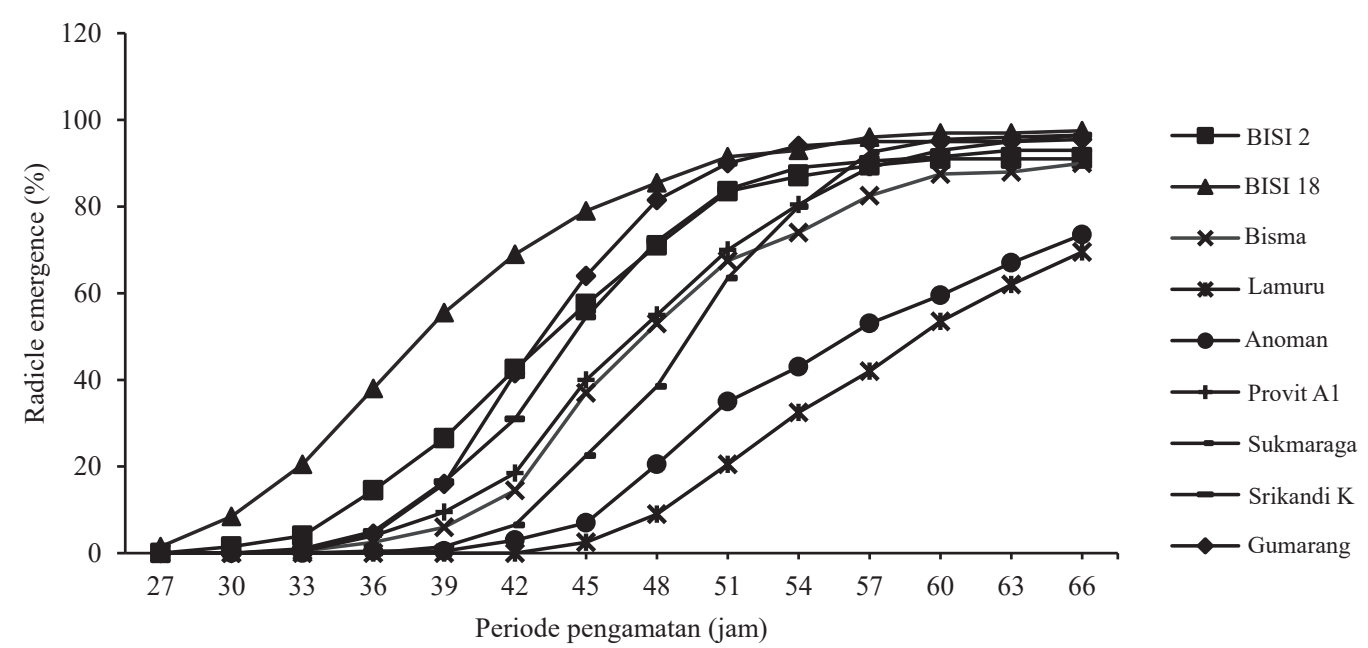

Gambar 1. Persentase radicle emergence (RE) pada sembilan varietas benih jagung mulai dari jam ke-27 sampai jam ke-66 setelah pengecambahan pada setiap selang 3 jam

Nilai RE menunjukkan kesamaan pola dengan peubah mutu yang diamati di laboratorium dan lapangan. Lot benih varietas BISI 18 yang merupakan lot benih dengan mutu tertinggi pada peubah DB, IV, BKKN, LPK, MGT, DT, dan MET juga menunjukkan nilai RE yang tertinggi dan tercepat munculnya radikula sepanjang $2 \mathrm{~mm}$. Nilai RE semenjak 30 jam setelah pengecambahan dari lot benih varietas BISI 18 telah menunjukkan berbeda nyata dengan lot benih lainnya. Pada periode pengamatan selanjutnya lot benih varietas BISI 18 terus menunjukkan kecepatan pemunculan radikula tercepat dibanding lot benih lainnya. Pada akhir periode pengamatan (66 jam setelah dikecambahkan) lot benih varietas BISI 18 juga menunjukkan nilai RE yang tertinggi. Nilai RE lot benih varietas Gumarang sedikit lebih rendah pada periode pengamatan di awal. Hal ini menunjukkan adanya perbedaan kecepatan pemunculan radikula antara lot benih varietas BISI 18 dengan Gumarang walaupun pada periode pengamatan 51 jam setelah pengecambahan kedua lot tersebut menunjukkan nilai RE yang relatif sama. Sementara itu, lot benih varietas Anoman dan Lamuru yang merupakan lot benih dengan mutu terendah pada peubah DB, IV, BKKN, LPK, MGT, DT, dan MET juga menunjukkan nilai RE yang terendah dan terlambat dalam memunculkan radikula dibanding lot benih lainnya. Lot benih varietas BISI 2, Srikandi Kuning, Provit A1, Bisma, Sukmaraga menunjukkan tingkatan performa diantara BISI 18 dan Anoman/Lamuru.

Grafik pertambahan RE pada jam pengamatan tertentu dapat membantu dalam menentukan satu waktu pengamatan (single count) RE yang tepat, seperti yang dilakukan Matthews dan Powell (2011) untuk menduga vigor benih dan bibit. Grafik pertambahan RE setiap selang 3 jam antara 27 sampai 66 jam setelah dikecambahkan disajikan pada Gambar 1. Nilai RE mulai stabil pada saat pengamatan 51 jam setelah dikecambahkan pada varietas BISI 18, Gumarang, BISI 2, dan Srikandi Kuning. Varietas Bisma, Provit A1, dan Sukmaraga mulai stabil pada jam pengamatan ke-57. Namun, varietas Lamuru dan Anoman yang dikategorikan sebagai varietas bervigor terendah dibanding lot benih lainnya masih mengalami peningkatan persentase RE hingga akhir periode pengecambahan.

Uji RE yang dilakukan dengan waktu pengamatan mulai dari 30 jam hingga 66 jam setelah dikecambahkan pada dasarnya sudah mampu menunjukkan perbedaan vigor antar lot benih varietas yang diuji. Pengamatan lebih lanjut dilakukan untuk menentukan titik waktu pengamatan setelah dikecambahkan yang paling berkorelasi sekaligus dapat dengan handal memprediksi peubah mutu lainnya (khususnya MGT). Hal ini sesuai dengan yang dilakukan Matthews dan Powell (2011) dimana penentuan waktu yang tepat (single count) untuk pengamatan RE didasarkan pada korelasi (r) dan kehandalan $\left(\mathrm{R}^{2}\right)$ prediksinya terhadap MGT.

Persentase RE pada waktu pengamatan 48 jam, 51 jam, dan 54 jam setelah pengecambahan menunjukkan variasi nilai $\mathrm{r}$ dan $\mathrm{R}^{2}$ (Tabel 3) terhadap peubah mutu benih lainnya. Waktu pengamatan RE pada 51 jam setelah dikecambahkan dipilih sebagai waktu pengamatan RE yang paling optimum. Hal ini didasarkan pada korelasinya yang erat dan nilai $\mathrm{R}^{2}$ yang tinggi dengan MGT $\left(\mathrm{r}=-0.93, \mathrm{R}^{2}=\right.$ $0.86, y=-0.196 x+61.46)$. Pada penelitian ini, walaupun RE pada waktu pengamatan 48 jam setelah dikecambahkan memiliki nilai koefisien korelasi dan determinasi antara RE dan MGT lebih tinggi daripada periode pengamatan 51 jam, akan tetapi nilai koefisien korelasi dan determinasi antara RE 48 jam dengan tolok ukur lain selain MGT tidak lebih baik daripada jam ke-51. Sementara itu waktu pengamatan 54 jam tidak lebih optimum karena memiliki nilai korelasi dan determinasi yang lebih rendah dibandingkan 51 jam antara RE dengan MGT.

Hubungan uji RE dengan peubah lain juga perlu dipertimbangkan agar akurasi uji RE dalam menggambarkan mutu benih menjadi lebih baik. Berbagai hasil penelitian menunjukkan adanya korelasi erat antara RE dengan vigor benih, yaitu pada benih jagung manis (Luo et al., 2015), kedelai (Astuti et al., 2020), alfalfa (Cheshmi dan Hosseini, 2020), dan bawang merah (Kamanga et al., 2021). Hasil uji RE juga berkorelasi erat dengan daya simpan benih 
Tabel 3. Hubungan linier antara nilai radicle emergence (RE) pada pengamatan 48, 51, dan 54 jam dengan berbagai tolok ukur mutu benih dan vigor bibit di lapangan

\begin{tabular}{|c|c|c|c|}
\hline Tolok ukur & $\mathrm{r}$ & $\mathrm{R}^{2}$ & Persamaan garis \\
\hline \multicolumn{4}{|c|}{ Periode pengecambahan 48 jam } \\
\hline DB & $0.83 * *$ & 0.69 & $y=0.266 x+75.18$ \\
\hline MGT & $-0.95 * *$ & 0.91 & $y=-0.178 x+57.88$ \\
\hline IV & $0.83 * *$ & 0.69 & $y=0.456 x+7.185$ \\
\hline $\mathrm{K}_{\mathrm{CT}}$ & $0.71 *$ & 0.51 & $y=0.187 x+21.42$ \\
\hline MET & $-0.72 *$ & 0.52 & $y=-0.014 x+5.988$ \\
\hline \multicolumn{4}{|c|}{ Periode pengecambahan 51 jam } \\
\hline DB & $0.86^{* *}$ & 0.73 & $y=0.310 x+68.65$ \\
\hline MGT & $-0.93 * *$ & 0.86 & $y=-0.196 x+61.46$ \\
\hline IV & $0.84 * *$ & 0.71 & $y=0.525 x-3.543$ \\
\hline $\mathrm{K}_{\mathrm{CT}}$ & $0.76^{*}$ & 0.57 & $y=0.225 x+16.38$ \\
\hline MET & $-0.79 *$ & 0.63 & $y=-0.017 x+6.403$ \\
\hline \multicolumn{4}{|c|}{ Periode pengecambahan 54 jam } \\
\hline DB & $0.87 * *$ & 0.76 & $y=0.355 x+62.94$ \\
\hline MGT & $-0.87 * *$ & 0.76 & $y=-0.208 x+63.78$ \\
\hline IV & $0.80 * *$ & 0.65 & $y=0.564 x-10.35$ \\
\hline $\mathrm{K}_{\mathrm{CT}}$ & $0.78 *$ & 0.61 & $y=0.261 x+11.96$ \\
\hline MET & $-0.79 *$ & 0.63 & $y=-0.019 x+6.704$ \\
\hline
\end{tabular}

Keterangan: $\mathrm{DB}=$ daya berkecambah; $\mathrm{MGT}=$ mean germination time $; \mathrm{IV}=$ indeks vigor; $\mathrm{K}_{\mathrm{CT}}=$ kecepatan tumbuh; $\mathrm{MET}=$ mean emergence time, $\mathrm{R}^{2}=$ koefisien determinasi; $\mathrm{r}=$ koefisien korelasi; $* *=$ berkorelasi sangat erat; $*=$ berkorelasi erat

leek (Ozden et al., 2017). Dalam pengembangan uji vigor benih, korelasinya dengan performa bibit di lapangan sangat penting. Penelitian terdahulu membuktikan hubungan erat antara RE dan daya tumbuh di lapangan antara lain pada benih kedelai (Astuti et al., 2020), marigold (Ilbi et al., 2020), dan bawang merah (Kamanga et al., 2021). Korelasi RE dengan MET dilaporkan pada benih kedelai (Astuti et al., 2020) dan bawang merah (Kamanga et al., 2021). Sebelumnya, Matthews et al. (2011) melaporkan bahwa MGT dan RE berkorelasi dengan laju pemunculan bibit jagung di lapangan. Selain itu, RE juga berkorelasi erat dengan daya hantar listrik benih dan daya berkecambah (Matthews et al., 2018; Marin et al., 2018). Korelasi erat antara RE dan daya berkecambah juga terjadi pada benih kedelai (Astuti et al., 2020), onion (Demir et el., 2020), dan bawang merah (Kamanga et al., 2021). Ini mengindikasikan, nilai RE dapat memprediksi daya berkecambah. Apabila uji RE dapat digunakan sebagai pengganti uji daya berkecambah, maka akan sangat mempercepat periode pengujian mutu benih.

Hasil penelitian ini membuktikan bahwa suhu perkecambahan $25^{\circ} \mathrm{C}$ dapat digunakan untuk uji RE pada benih jagung karena nilai $r$ dan $\mathrm{R}^{2}$ yang tinggi terhadap beberapa tolok ukur viabilitas dan vigor benih. Konsekuensi penggunaan suhu yang lebih tinggi pada penelitian ini adalah lebih cepatnya waktu pengamatan RE ( 51 jam) dibandingkan pada suhu uji RE $20^{\circ} \mathrm{C}$ (66 jam) yang telah divalidasi ISTA. Suhu mempengaruhi persentase dan laju perkecambahan, semakin tinggi suhu hingga suhu optimum, semakin cepat perkecambahan. Menurut Edalat dan Kazemeini (2014), suhu kardinal benih jagung untuk tumbuh di lapangan (field emergence) berkisar 28.9-30 ${ }^{\circ} \mathrm{C}$. Penggunaan suhu yang berbeda sudah dilaporkan oleh Matthews dan Powell (2011) yang memberikan alternatif suhu antara $20{ }^{\circ} \mathrm{C}$ atau suhu $13{ }^{\circ} \mathrm{C}$. Konsekuensi penggunaan suhu yang lebih rendah adalah makin lamanya waktu pengamatan $\mathrm{RE}$ dari 66 jam pada suhu $20^{\circ} \mathrm{C}$ menjadi 6 hari pada suhu $13{ }^{\circ} \mathrm{C}$. Penggunaan suhu $25^{\circ} \mathrm{C}$ juga dilaporkan dapat dilakukan pada uji RE benih padi dan kacang hijau (Onwimol et al., 2016), benih terong (Ozden et al., 2018), dan benih bawang merah (Kamanga et al., 2021).

\section{Analisis Korelasi dan Regresi}

Pola urutan vigor antar lot benih beberapa varietas jagung yang sesuai antara banyak peubah dengan RE juga dapat dijelaskan secara kuantitatif melalui korelasi dan regresi. Korelasi yang sangat erat dan hubungan linier positif ditunjukkan antara RE jam ke-51 dan DB, 73\% keragaman nilai DB dapat dijelaskan oleh nilai RE melalui persamaan $\mathrm{y}=0.310 \mathrm{x}+68.65$ (Gambar 2A). Terdapat korelasi yang sangat erat dan hubungan linier negatif antara RE jam ke-51 dengan MGT, artinya semakin tinggi nilai RE maka nilai MGT semakin rendah. Nilai koefisien determinasi yang besar (0.86) antara RE dan MGT melalui persamaan $\mathrm{y}=$ 
$-0.196 x+61.46$ (Gambar 2B). Nilai RE jam ke-51 juga berkorelasi erat dan linier positif dengan IV (Gambar 2C) dan $\mathrm{K}_{\mathrm{CT}}$ (Gambar 2D). Semakin tinggi nilai RE maka nilai IV dan $\mathrm{K}_{\mathrm{CT}}$ juga semakin tinggi. Gambar $2 \mathrm{E}$ menunjukkan, terdapat korelasi negatif antara RE pada jam ke-51 dengan MET, artinya semakin tinggi nilai RE maka nilai MET semakin rendah. Keragaman nilai MET sebesar $62 \%\left(\mathrm{R}^{2}\right.$ $=0.62$ ) dapat dijelaskan oleh RE melalui persamaan $\mathrm{y}=$ $0.017 x+6.403$. Hasil percobaan ini menunjukkan nilai $\mathrm{RE}$ pada jam pengamatan ke-51 berhubungan erat dengan nilai DB, MGT, IV, $\mathrm{K}_{\mathrm{CT}}$, dan MET. Penelitian Astuti et al. (2020) pada benih kedelai menunjukkan nilai RE yang diamati saat 42 jam setelah dikecambahkan pada suhu $25^{\circ} \mathrm{C}$ berkorelasi dengan DB, MGT, IV, $\mathrm{K}_{\mathrm{CT}}$, DT, dan MET. Kamanga et al. (2021) juga membuktikan bahwa uji RE pada benih bawang merah berkorelasi erat dengan $\mathrm{DB}, \mathrm{MGT}, \mathrm{IV}, \mathrm{K}_{\mathrm{CT}}$, daya hantar listrik, DT, dan MET.
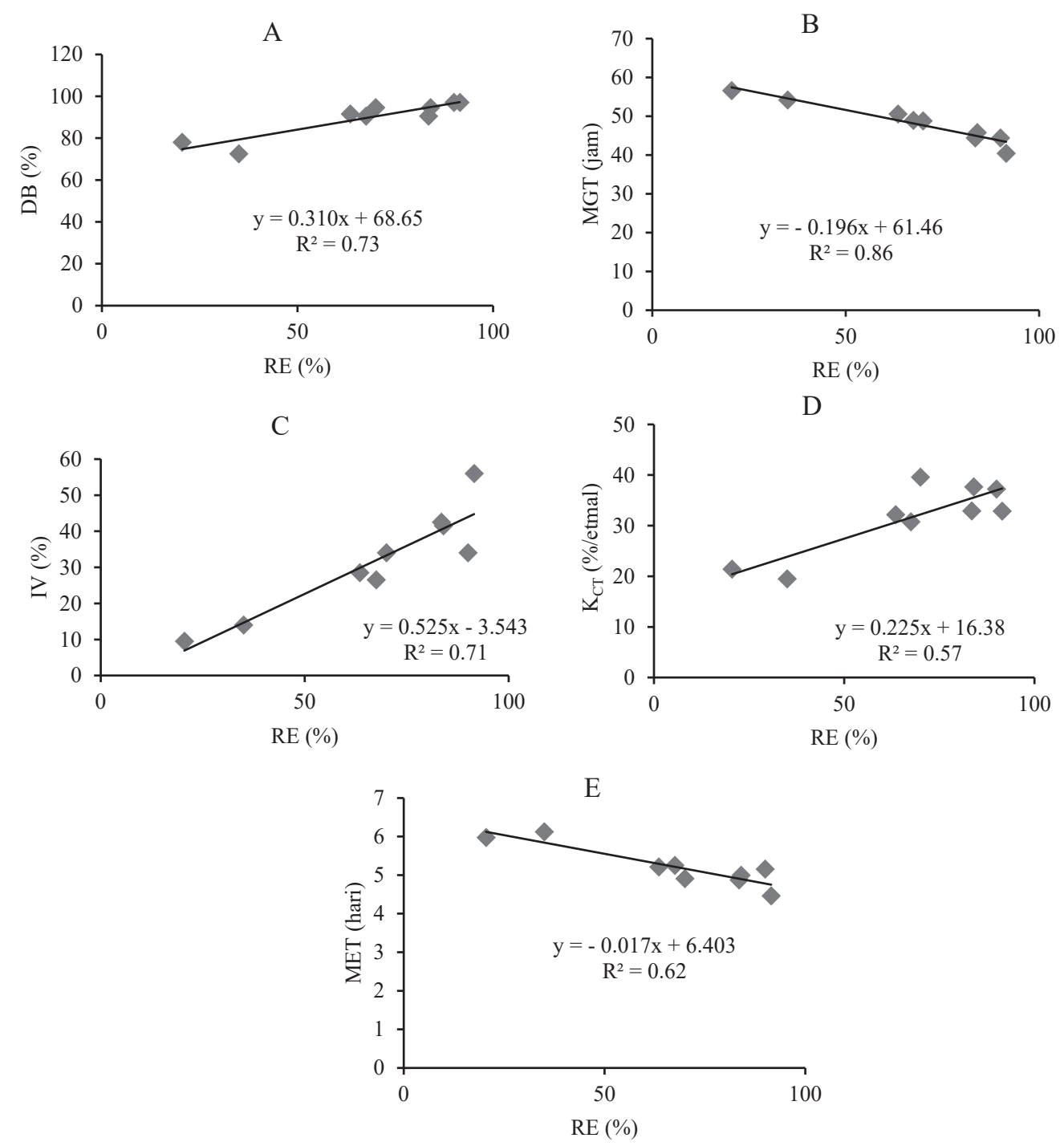

Gambar 2. Grafik hubungan linier antara nilai RE pada periode pengecambahan 51 jam dengan daya berkecambah (DB) (A), mean germination time $(\mathrm{MGT})(\mathrm{B})$, indeks vigor $(\mathrm{IV})(\mathrm{C})$, kecepatan tumbuh $\left(\mathrm{K}_{\mathrm{CT}}\right)(\mathrm{D})$, mean emergence time $(\mathrm{MET})(\mathrm{E})$

\section{KESIMPULAN}

Uji vigor pemunculan radikula atau radicle emergence (RE) benih jagung pada suhu $25^{\circ} \mathrm{C}$ dapat mempersingkat periode pengujian dari 66 jam (rekomendasi ISTA pada pengujian RE benih jagung dengan suhu $20^{\circ} \mathrm{C}$ ) menjadi 51 jam setelah dikecambahkan. Uji RE ini terbukti berkorelasi sangat erat dengan daya berkecambah $\left(R^{2}=0.73, r=0.85\right)$, mean germination time (MGT) $\left(\mathrm{R}^{2}=0.86, \mathrm{r}=-0.92\right)$, dan indeks vigor $\left(\mathrm{R}^{2}=0.71, \mathrm{r}=0.84\right)$, serta berkorelasi erat dengan kecepatan tumbuh $\left(\mathrm{R}^{2}=0.57, \mathrm{r}=0.76\right)$ dan mean emergence time $(\mathrm{MET})\left(\mathrm{R}^{2}=0.62, \mathrm{r}=-0.79\right)$. Radicle emergence dapat menduga daya berkecambah $(\mathrm{y}=0.310 \mathrm{x}$ $+68.65)$, MGT $(\mathrm{y}=-0.196 \mathrm{x}+61.46)$, indeks vigor $(\mathrm{y}=$ $0.525 \mathrm{x}-3.543), \mathrm{K}_{\mathrm{CT}}(\mathrm{y}=0.225 \mathrm{x}+16.38)$, dan MET $(\mathrm{y}=$ $-0.017 \mathrm{x}+6.403)$. 


\section{DAFTAR PUSTAKA}

Astuti, F., C. Budiman, S. Ilyas. 2020. Pengembangan metode uji cepat vigor benih kedelai dengan pemunculan radikula. J. Agron. Indonesia 48:135-141.

Cheshmi, M., M.K. Hosseini. 2020. Single count of radicle emergence, DNA replication during seed germination and vigour in alfalfa seed lots. Seed Sci. Technol. 48:367-380.

Demir I., T. Celikkol, G. Sarıkamıs, C. Eksi. 2011. Vigor tests to estimate seedling emergence potential and longevity in viola seed lots. HortScience 46:402405.

Demir, I., E. Ozden, Z. Gokdas, E.S. Enjie, M. Aydin. 2020. Radicle emergence test predicts normal germination percentages of onion seed lots with different cultivars and genotypes. MKU. J. Agric. Sci. 25:434-442.

Edalat, M., S.A. Kazemeini. 2014. Estimation of cardinal temperatures for seedling emergence in corn. AJCS 8:1072-1078.

[ISTA] International Seed Testing Association. 2014. International Rules for Seed Testing. Bassersdorf.

Ilbi, H., A.A. Powell, O. Alan. 2020. Single radicle emergence count for predicting vigour of marigold (Tagetes spp.) seed lots. Seed Sci. Technol. 48:381389 .

Ilyas, S. 2012. Ilmu dan Teknologi Benih, Teori dan Hasilhasil Penelitian. Bogor, IPB press, ID.

Kamanga, B.M., E.R. Palupi, E. Widajati, S. Ilyas. 2021. Development of seed vigour testing method using single count of radicle emergence for true seed of shallot (Allium ascalonicum B.). Internat. J. Sci. Food Agric. 5:152-162.

Luo, Y., Y.J. Guan, Y.T. Huang, J. Li, Z. Li, J. Hu. 2015. Single counts of radicle emergence provide an alternative method to test seed vigour in sweet corn. Seed Sci. Technol. 43:519-525.
Marin, M., G. Laverack, A.A. Powell, S. Matthews. 2018. Potential of the electrical conductivity of seed soak water and early counts of radicle emergence to assess seed quality in some native species. Seed Sci. Technol. 46:71-86.

Matthews, S., E. Beltrami, R. El-Khadem, M.K. Hosseini, M. Nasehzadeh, G. Urso. 2011. Evidence that time for repair during early germination leads to vigour differences in maize. Seed Sci. Technol. 39:501-509.

Matthews, S., A. Powell. 2011. Towards automated single counts of radicle emergence to predict seed and seedling vigour. Seed Testing Intl. 142:44-48.

Matthews, S., M.H. Wagner, L. Kerr, A.A. Powell. 2018. Potential for early counts of radicle emergence and leakage of electrolytes as quick tests to predict the percentage of normal seedlings. Seed Sci. Technol. 46:1-18.

Onwimol, D., S. Chanprame, T. Thongket. 2012. Arrest of cell cycle associated with delayed radicle emergence in deteriorated cucumber seed. Seed Sci. Technol. 40:238-247.

Onwimol, D., W. Chanmprasert, P. Changsee. 2016. Seed vigor classification using analysis of mean radicle emergence time and single counts of radicle emergence in rice (Oryza sativa L.) and mung bean (Vigna radiata (L.) Wilczek). Agric. Nat. Resour. 50:345-350.

Ozden, E., C. Ozdamar, I. Demir. 2018. Radicle emergence test estimates predictions of percentage normal seedlings in standard germination tests of aubergine (Solanum melongena L.) seed lots. Not Bot. Horti. Agrobo. 46:177-182.

Ozden, E., K. Mavi, E. Sari, I. Demir. 2017. Radicle emergence test predicts longevity (half viability period, p50) of leek seed lots. Seed Sci. Technol. 45: 243-247.

Yin, M.Q., W.J. Song, G.Y. Guo, F. Li, M.S. Sheteiwy, R.H. Pan, J. Hu, Y.J. Guan. 2018. Starchy degradation is related with radicle emergence during wheat seed germination. Seed Sci. Technol. 46:359-364. 